\title{
Improved production of biohydrogen in light- powered Escherichia coli by co-expression of proteorhodopsin and heterologous hydrogenase
}

\author{
Jaoon YH Kim ${ }^{1}$, Byung Hoon Jo2, Younghwa Jo ${ }^{1}$ and Hyung Joon Cha ${ }^{1,2^{*}}$
}

\begin{abstract}
Background: Solar energy is the ultimate energy source on the Earth. The conversion of solar energy into fuels and energy sources can be an ideal solution to address energy problems. The recent discovery of proteorhodopsin in uncultured marine $\gamma$-proteobacteria has made it possible to construct recombinant Escherichia coli with the function of light-driven proton pumps. Protons that translocate across membranes by proteorhodopsin generate a proton motive force for ATP synthesis by ATPase. Excess protons can also be substrates for hydrogen $\left(\mathrm{H}_{2}\right)$ production by hydrogenase in the periplasmic space. In the present work, we investigated the effect of the coexpression of proteorhodopsin and hydrogenase on $\mathrm{H}_{2}$ production yield under light conditions.

Results: Recombinant E. coli BL21(DE3) co-expressing proteorhodopsin and [NiFe]-hydrogenase from Hydrogenovibrio marinus produced $\sim 1.3$-fold more $\mathrm{H}_{2}$ in the presence of exogenous retinal than in the absence of retinal under light conditions $\left(70 \mu\right.$ mole photon $\left./\left(\mathrm{m}^{2} \cdot \mathrm{s}\right)\right)$. We also observed the synergistic effect of proteorhodopsin with endogenous retinal on $\mathrm{H}_{2}$ production ( $\sim 1.3$-fold more) with a dual plasmid system compared to the strain with a single plasmid for the sole expression of hydrogenase. The increase of light intensity from 70 to $130 \mu$ mole photon/( $\left.\mathrm{m}^{2} . \mathrm{s}\right)$ led to an increase ( 1.8-fold) in $\mathrm{H}_{2}$ production from 287.3 to $525.7 \mathrm{~mL} \mathrm{H}_{2} / \mathrm{L}$-culture in the culture of recombinant $E$. coli co-expressing hydrogenase and proteorhodopsin in conjunction with endogenous retinal. The conversion efficiency of light energy to $\mathrm{H}_{2}$ achieved in this study was $\sim 3.4 \%$.

Conclusion: Here, we report for the first time the potential application of proteorhodopsin for the production of biohydrogen, a promising alternative fuel. We showed that $\mathrm{H}_{2}$ production was enhanced by the co-expression of proteorhodopsin and [NiFe]-hydrogenase in recombinant E. coli BL21(DE3) in a light intensity-dependent manner. These results demonstrate that $E$. coli can be applied as light-powered cell factories for biohydrogen production by introducing proteorhodopsin.
\end{abstract}

Keywords: biohydrogen, Escherichia coli, proteorhodopsin, light-driven proton pump, light-powered cell factory

\section{Background}

Since the Industrial Revolution, energy consumption has increased exponentially and most energy has been derived from fossil fuels. Currently, we still depend on fossil fuels for more than 80 percent of our demands for electricity, transportation, and industries, although concerns about the exhaustion of fossil fuels and global warming have led to increased attention to renewable

\footnotetext{
* Correspondence: hjcha@postech.ac.kr

'Department of Chemical Engineering, Pohang University of Science and Technology, Pohang 790-784, Korea

Full list of author information is available at the end of the article
}

energy [1]. Among various renewable energy sources, solar energy is the most abundant and ultimate source. The total amount of solar energy absorbed by the Earth's surface is $1.74 \times 10^{5}$ terawatts (TW) [2], which is a tremendous amount compared to the world's energy consumption $(\sim 13 \mathrm{TW})$ [1]. Thus, the conversion of solar energy to fuels may constitue the most sustainable way to solve the energy crisis.

In the field of biotechnology, the photosynthetic process in algae and cyanobacteria has been actively investigated for the conversion of solar energy to useful biofuels [3-5]. Photosynthesis requires a highly complex
Ciomed Central

() 2012 Kim et al; licensee BioMed Central Ltd. This is an Open Access article distributed under the terms of the Creative Commons Attribution License (http://creativecommons.org/licenses/by/2.0), which permits unrestricted use, distribution, and reproduction in any medium, provided the original work is properly cited. 
photosystem composed of numerous proteins and photosynthetic enzymes, such as Rubisco [1]. In addition, many challenges still remain for engineering photosynthetic microorganisms $[1,6]$. Recently, a new type of rhodopsin, called proteorhodopsin, was discovered in the metagenome of uncultured marine $\gamma$-proteobacteria [7]. Proteorhodopsin can be heterologously expressed in Escherichia coli to possess proton-pumping activity [7], which is different from bacteriorhodopsin found in halobacteria $[1,8]$. This property of proteorhodopsin enables the investigation of its impact on cellular energy and phototrophy [8]. There have also been reports of the enhancement of cell viability or growth via light-driven proton pumping by proteorhodopsin under nutrientlimited conditions [9-11]. However, there have been no substantial applications in biofuel production using proteorhodopsin, although this potential has been mentioned recently [1].

Hydrogen $\left(\mathrm{H}_{2}\right)$ has been recognized as one promising alternative energy source to fossil fuels. It does not emit carbon dioxide during combustion and can be easily converted to electricity using fuel cells. In addition, it has a higher energy density than other energy sources. Although the current production of $\mathrm{H}_{2}$ mainly depends on thermochemical methods using fossil fuels [12], biological approaches have been actively investigated to generate $\mathrm{H}_{2}$ in a more sustainable manner [13-17]. Among them, photobiological $\mathrm{H}_{2}$ production has attracted great attention due to its eco-friendly properties, such as its usage of solar energy and carbon assimilation. Nevertheless, there are still many obstacles to overcome, including slow cell growth, the low conversion efficiency of light to $\mathrm{H}_{2}$, the inhibitory effect of oxygen on hydrogenase activity, and others [16,17].

$E$. coli has been used widely as a cell factory for many types of bio-products (including biofuels), but it cannot utilize light energy. Therefore, constructing E. coli capable of absorbing light energy and converting it to other biofuels through the introduction of proteorhodopsin might increase biofuel production efficiency. It has been shown that protons generated by rhodopsin can migrate along the membrane surface [18] and thus, they can act as substrates of hydrogenase for $\mathrm{H}_{2}$ evolution. Thus, in the present work, for the first time (to our knowledge), we introduced proteorhodopsin into $E$. coli, generating bacteria capable of utilizing light and investigated its effect on $\mathrm{H}_{2}$ production yield using the previously constructed recombinant E. coli expressing Hydrogenovibrio marinus-originated [NiFe]-hydrogenase [15].

\section{Results}

Functional expression of proteorhodopsin in $E$. coli

$E$. coli does not have an intrinsic ability to absorb light energy. We constructed a plasmid, pACYC-RDS including 6 genes ( $\operatorname{crt} E, B, I, Y, b$-diox, and $p R)$, that are required for the functional heterologous expression of proteorhodopsin in E. coli (Figure 1). The recombinant E. coli BL21(DE3) harboring pACYC-RDS was cultured, and protein expression was induced under exposure to $70 \mu \mathrm{mol}$ photon $/\left(\mathrm{m}^{2} \cdot \mathrm{s}\right)$ light. From the harvested cell pellet, we observed that the cells expressing proteorhodopsin with endogenous retinal have a distinctively reddish color compared to wild-type cells (Figure 2A). In addition, we confirmed that the membrane fraction, including recombinant proteorhodopsin (generated by the expression of a single $p R$ gene), absorbs light at a specific wavelength of $520 \mathrm{~nm}$ in the presence of exogenous retinal, indicating the functional expression of recombinant proteorhodopsin in E. coli (Figure 2B).

\section{Co-expression effect of proteorhodopsin and hydrogenase on $\mathrm{H}_{2}$ production}

After confirmation of proteorhodopsin function in recombinant $E$. coli, we investigated the effect of coexpressing proteorhodopsin and $H$. marinus [NiFe]hydrogenase on $\mathrm{H}_{2}$ production. We used two kinds of expression systems: a single plasmid system of $\mathrm{pET}-\mathrm{HmH} / \mathrm{pR}$ (without endogenous retinal) and a dual plasmid system of pET-HmH and pACYC-RDS (with endogenous retinal) (Figure 1). E. coli BL21(DE3) transformed with $\mathrm{pET}-\mathrm{HmH} / \mathrm{pR}$ or cotransformed with $\mathrm{pET}$ $\mathrm{HmH}$ and pACYC-RDS was cultured in $125 \mathrm{~mL}$ serum bottles under exposure to $70 \mu \mathrm{mol}$ photon $/\left(\mathrm{m}^{2} \cdot \mathrm{s}\right)$ light. We found that $E$. coli with $\mathrm{pET}-\mathrm{HmH} / \mathrm{pR}$ produced more $\mathrm{H}_{2}$ after retinal addition under light than the cells without retinal (Figure 3A). This result indicates that the gained function of recombinant proteorhodopsin by the addition of retinal has a synergistic effect on $\mathrm{H}_{2}$ production with the heterologous expression of hydrogenase. A negative control strain containing the parent

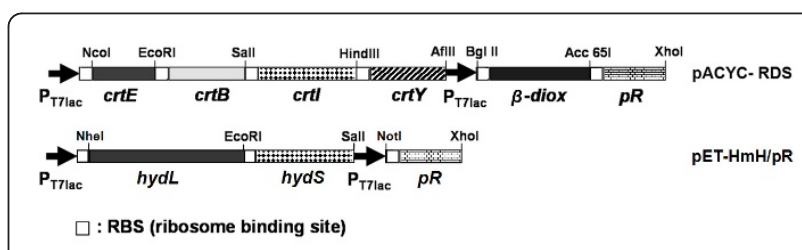

Figure 1 Plasmid maps for the expression of proteorhodopsin in E. coli. Erwinia uredovora crt E, B, I, Y (for $\beta$-carotene synthesis), mouse $\beta$-diox gene (for conversion of $\beta$-carotene to retinal), and $p R$ gene coding proteorhodopsin were cloned into PACYC-Duet1 vector to construct PACYC-RDS. All of the genes were amplified using the primers in Table 1 and digested using restriction enzymes for cloning into pACYC-Duet1. pET-HmH/pR was constructed by cloning a single $p R$ gene into $p E T-H m H$, which expresses $H$. marinus [NiFe]-hydrogenase, to investigate the function of proteorhodopsin with exogenous retinal. pACYC-pR (without $c r t E, B, I, Y, \beta$-diox) was also constructed to measure the absorption spectrum of $E$. coli with membranes expressing proteorhodopsin (Figure 2B). 

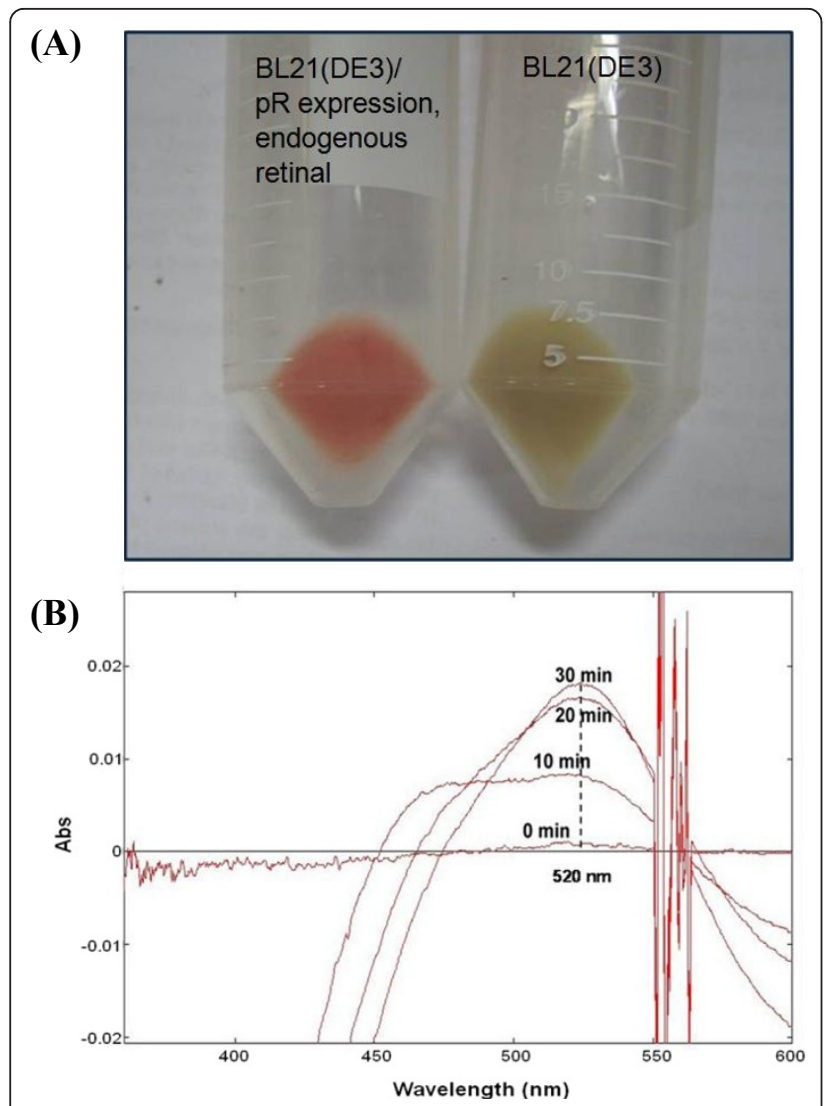

Figure 2 Functional heterologous expression of proteorhodopsin in E. coli. (A) Color-shift by expression of proteorhodopsin. Left sample: E. coli BL21(DE3)/pACYC-RDS (proteorhodopsin expression \& retinal synthesis), right sample: wildtype E. coli BL21(DE3). (B) Absorption spectra of the membrane of $E$. coli expressing proteorhodopsin alone. Membrane fractions in $50 \mathrm{mM}$ Tris- $\mathrm{Cl}\left(\mathrm{pH} \mathrm{8.0)}\right.$ and $5 \mathrm{mM} \mathrm{MgCl}_{2}$ were mixed with $20 \mu \mathrm{M}$ all-trans-retinal. Spectra were measured every $10 \mathrm{~min}$ for $30 \mathrm{~min}$.

vector (pET-21b) did not produce $\mathrm{H}_{2}$ under the same conditions. Using the dual plasmid system for endogenous retinal biosynthesis, we also observed similar results (Figure $3 \mathrm{~B})$. The BL21(DE3) strain with the dual plasmid system (pET-HmH and pACYC-RDS) also produced $\sim 1.3$-fold more $\mathrm{H}_{2}$ compared to the strain expressing hydrogenase (pET-HmH) alone. Although the strain harboring two plasmids showed lower $\mathrm{H}_{2}$ production than the strain expressing only hydrogenase at $12 \mathrm{~h}$, its production rapidly increased and surpassed the $\mathrm{H}_{2}$ production of the hydrogenaseonly strain after $19 \mathrm{~h}$ (Figure 3B).

\section{Light intensity effect on $\mathrm{H}_{2}$ production by co-expression of proteorhodopsin and hydrogenase}

To investigate the effect of light energy on $\mathrm{H}_{2}$ production by the co-expression of proteorhodopsin and hydrogenase, light intensity was changed during the

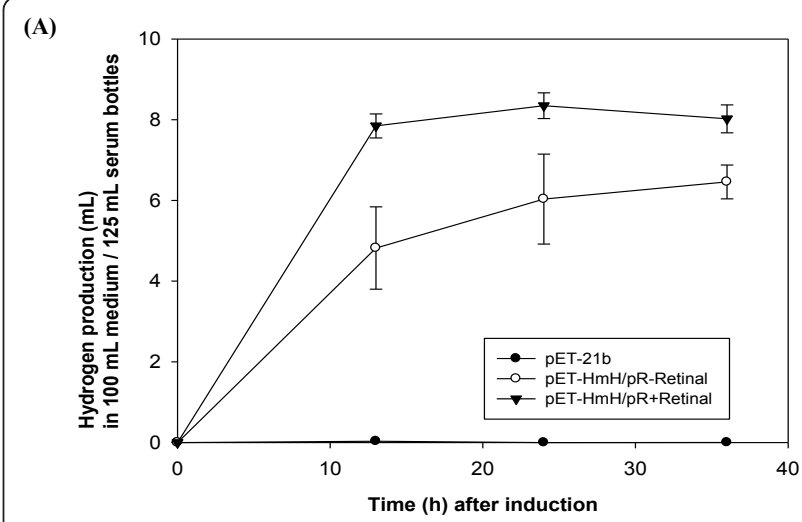

(B)

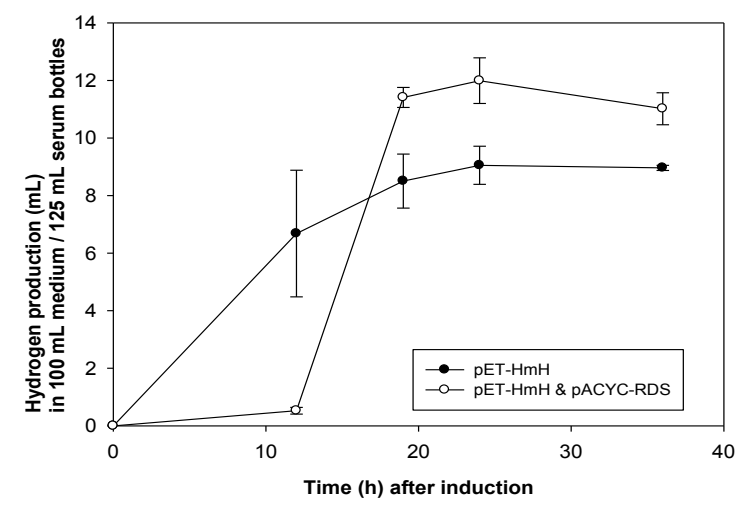

Figure 3 Co-expression effect of proteorhodopsin and hydrogenase on $\mathrm{H} 2$ production. (A) Co-expression effect of proteorhodopsin with exogenous retinal and hydrogenase on $\mathrm{H}_{2}$ production. Recombinant E. coli BL21(DE3) with a single plasmid, $\mathrm{pET}-\mathrm{HmH} / \mathrm{pR}$, were grown with or without retinal under a light intensity of 70 umole photon $/\left(\mathrm{m}^{2} \cdot \mathrm{s}\right)$. E. coli harboring the parent pET-21b vector was used as a negative control. (B) Co-expression effect of proteorhodopsin with endogenous retinal and hydrogenase on $\mathbf{H}_{\mathbf{2}}$ production. Recombinant E. coli BL21(DE3) with two plasmids, pET-HmH and PACYC-RDS, were grown under the same light conditions. $\mathrm{H}_{2}$ production was measured using GC as described in the Methods. Each value and its error bars represent the mean of two independent cultures and the standard deviation, respectively.

culture. We increased light intensity from $70 \mu$ mole photon $/\left(\mathrm{m}^{2} \cdot \mathrm{s}\right)$ to $130 \mu$ mole photon $/\left(\mathrm{m}^{2} \cdot \mathrm{s}\right)$ at the middle part of culture bottles by changing the light source from two $20 \mathrm{~W}$ fluorescent lamps to two $30 \mathrm{~W}$ fluorescent lamps. We observed that the cells cultured at a light intensity of $130 \mu$ mole photon $/\left(\mathrm{m}^{2} \cdot \mathrm{s}\right)$ produced more $\mathrm{H}_{2}$ than those cultured at $70 \mu$ mole photon $/\left(\mathrm{m}^{2} \cdot \mathrm{s}\right.$ ) (Figure $4)$. At $24 \mathrm{~h}$ after induction, the cells grown under 130 $\mu$ mole $/\left(\mathrm{m}^{2} \cdot \mathrm{s}\right)$ light produced $184 \pm 8.9 \mathrm{~mL} \mathrm{H}_{2}$ while cells grown under $70 \mu$ mole photon $/\left(\mathrm{m}^{2} \cdot \mathrm{s}\right)$ light produced $100.5 \pm 0.8 \mathrm{~mL} \mathrm{H}_{2}$, corresponding to yields of $525.7 \pm 25.4 \mathrm{~mL} \mathrm{H}_{2} / \mathrm{L}$-culture and $287.3 \pm 2.1 \mathrm{~mL} \mathrm{H}_{2} /$ L-culture, respectively. A production rate of $21.9 \mathrm{~mL}$ $\mathrm{H}_{2} /$ (L-culture.h) was achieved from the culture for $24 \mathrm{~h}$ 


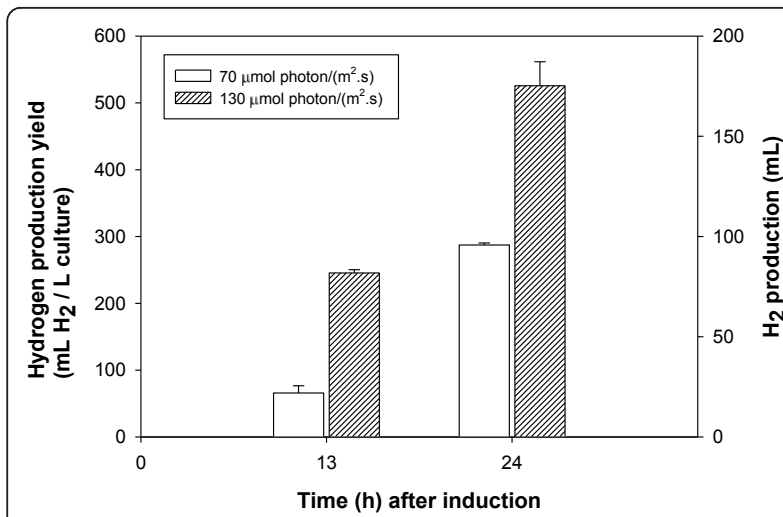

Figure 4 The effect of light intensity on $\mathrm{H}_{2}$ production by coexpression of proteorhodopsin and hydrogenase. Recombinant E. coli BL21(DE3) with two plasmids, pET-HmH and pACYC-RDS, were grown in $500 \mathrm{~mL}$ sealed serum bottles containing $350 \mathrm{~mL}$ M9 medium. Light intensity was adjusted to $70 \mu$ mole photon $/\left(\mathrm{m}^{2} \cdot \mathrm{s}\right)$ or $130 \mu$ mole photon $/\left(\mathrm{m}^{2} \cdot \mathrm{s}\right) . \mathrm{H}_{2}$ production was measured using GC. Each value and error bars represent the mean of two independent cultures and the standard deviation.

at a light intensity of $130 \mu$ mole photon $/\left(\mathrm{m}^{2} \cdot \mathrm{s}\right)$. Cell growth was similar between the two cultures under different light conditions (data not shown). This indicated that improved $\mathrm{H}_{2}$ production $\left(0.0835 \mathrm{~L} \mathrm{H}_{2}\right.$, equivalent to $0.902 \mathrm{~kJ})$ was derived from enhanced light energy $(60$ umole photon $/\left(\mathrm{m}^{2} \cdot \mathrm{s}\right)$ for $24 \mathrm{~h}$, equivalent to $\left.26.579 \mathrm{~kJ}\right)$. Thus, we might determine that the conversion efficiency of light energy to $\mathrm{H}_{2}$ was $\sim 3.4 \%$ in the present work using recombinant $E$. coli BL21 expressing both proteorhodopsin and $H$. marinus [NiFe]-hydrogenase.

\section{Discussion}

E. coli is a chemotroph that cannot utilize light energy. Bacteriorhodopsins, including proteorhodopsin, are the simplest molecules that enable microorganisms to utilize solar energy to create a proton gradient and generate ATP. In addition, protons translocated by rhodopsin can migrate along the membrane [18] and might be substrates of hydrogenase for the evolution of $\mathrm{H}_{2}$ (Figure 5). Thus, we tried to convert light energy to $\mathrm{H}_{2}$ by exploiting the light-driven proton-pumping function of proteorhodopsin in recombinant $E$. coli expressing hydrogenase.

We observed functional expression of proteorhodopsin in the recombinant E. coli BL21(DE3) and thus investigated the effect of co-expressing proteorhodopsin and $\mathrm{H}$. marinus [NiFe]-hydrogenase on $\mathrm{H}_{2}$ production. Using a single plasmid system expressing both hydrogenase and proteorhodopsin without biosynthesis of endogenous retinal, we found that $\mathrm{H}_{2}$ production was improved by $\sim 29 \%$ in the presence of added retinal under light. This indicates that proteorhodopsin

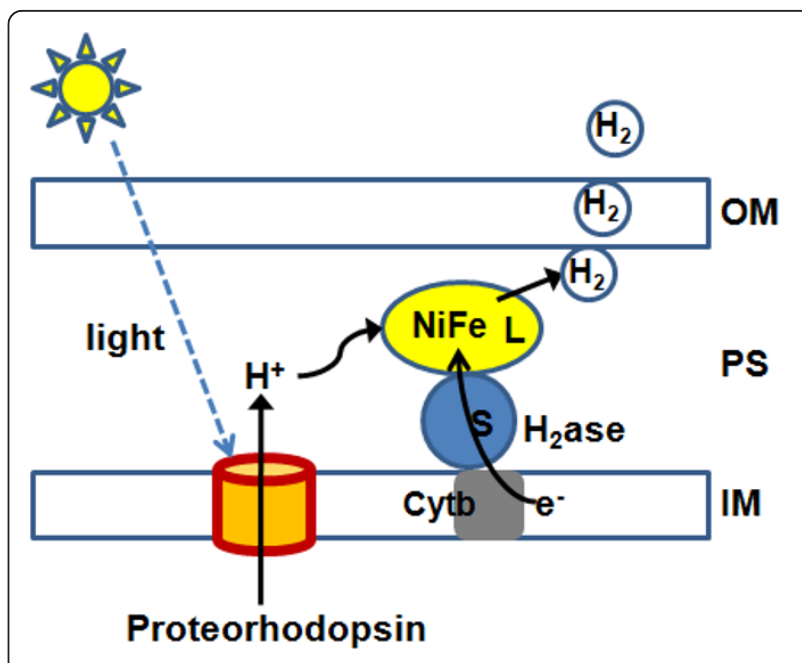

Figure 5 Schematic diagram of $\mathrm{H}_{2}$ production by the coexpression of proteorhodopsin and [NiFe]-hydrogenase in $E$. coli. Proteorhodopsin transports protons across the membrane by absorption of light energy. Protons are transferred to the active site in the large subunit $(\mathrm{L})$ of [NiFe]-hydrogenase in the periplasm and reduced to $\mathrm{H}_{2}$ by the addition of an electron, which is transferred thorough [Fe-S] clusters in the small subunit of [NiFe]-hydrogenase (S) and b-type cytochrome (Cyt b, encoded by hyaC in E. coli) in the inner membrane. Abbreviations: OM, outer membrane; PS,

periplasmic space; IM, inner membrane.

function, gained with exogenous retinal, provided a synergistic effect on $\mathrm{H}_{2}$ production through the supplementation of protons. Similarly to the single plasmid system, we also observed a positive effect of proteorhodopsin using a dual plasmid system. $\mathrm{H}_{2}$ production levels of cells co-expressing hydrogenase, proteorhodopsin, and retinal synthesis proteins was $\sim 1.3-$ fold higher at the final time point than that of the cells expressing only hydrogenase. It is noteworthy that $\mathrm{H}_{2}$ production from the strain co-expressing proteorhodopsin and hydrogenase quickly surpassed $\mathrm{H}_{2}$ production from the strain expressing only hydrogenase at a late phase. This retarded $\mathrm{H}_{2}$ production profile of the dual plasmid system might be attributed to the metabolic burden caused by the over-expression of multiple proteins required for the biosynthesis of retinal and proteorhodopsin.

Because the function of proteorhodopsin is driven by the absorption of light energy, light intensity can be a key factor for $\mathrm{H}_{2}$ production. We found that the $\mathrm{H}_{2}$ production from cells co-expressing hydrogenase and proteorhodopsin with endogenous retinal is strongly dependent on light intensity. Increasing the light intensity from $70 \mu$ mole photon $/\left(\mathrm{m}^{2} \cdot \mathrm{s}\right)$ to $130 \mu$ mole photon/ $\left(\mathrm{m}^{2} \cdot \mathrm{s}\right)$ increased $\mathrm{H}_{2}$ production yield $\sim 1.8$-fold. However, cell growth was not different in the two cultures under different light conditions. This tendency was consistent with a previous report that proteorhodopsin contributes 
to cell growth only under nutrient-limited conditions [9]. Thus, this indicates that $\mathrm{H}_{2}$ production was improved by the absorption of enhanced light energy through the proton-pumping function of proteorhodopsin. In the present study, it seems that the reduction from proton to $\mathrm{H}_{2}$ mediated by hydrogenase generates additional proton gradient, driving proteorhodopsin to pump protons, the substrates for hydrogenase. When we calculated the production rate per culture volume (21.9 $\mathrm{mL} \mathrm{H}_{2}$ (L-culture-h)) and the conversion efficiency of light energy to $\mathrm{H}_{2}(\sim 3.4 \%)$, the levels achieved in this study were comparable to the results of photobiological hydrogen production in previous studies: $\mathrm{H}_{2}$ production rate in green algae, $0.048-4.48 \mathrm{~mL} \mathrm{H}_{2}$ (L-culture.h), cyanobacteria, 4.03-13 $\mathrm{mL} \mathrm{H}_{2}$ /(L-culture.h), photosynthetic bacteria, 7.6-131 $\mathrm{mL} \mathrm{H}_{2}$ /(L-culture-h), and light conversion efficiency in photoautotrophs, $3-10 \%$ with removal of $\mathrm{O}_{2}$ or $1-2 \%$, and photoheterotrophs, $0.308-9.23 \%$ ) $[17,19]$. Although cell growth was mainly supported by exogenous nutrients in this system, these results are quite meaningful for the development of an $E$. coli system that can utilize light energy as a supplementary source.

\section{Conclusions}

Here, we demonstrated the substantial application of proteorhodopsin for light-driven biohydrogen production in a recombinant $E$. coli system. E. coli engineered to express $H$. marinus [NiFe]-hydrogenase and proteorhodopsin produced more $\mathrm{H}_{2}$ with the existence of retinal under light conditions. Engineered strains also produced more $\mathrm{H}_{2}$ as light intensity increased, although there was no difference in cell growth. These results suggest that our system works for converting light energy to $\mathrm{H}_{2}$ via the cooperation of proteorhodopsin and hydrogenase. In addition, engineering E. coli as light-powered cell factories could provide a solution for developing potential strategies for photobiological $\mathrm{H}_{2}$ production.

\section{Methods}

\section{Bacterial strains and culture conditions}

E. coli Top10 (Invitrogen, USA) was used for the manipulation and cloning of target genes. E. coli BL21 (DE3) (Novagen, USA) was used for expression of recombinant proteins. We used LB medium including proper antibiotics $(50 \mu \mathrm{g} / \mathrm{mL}$ ampicillin and $30 \mu \mathrm{g} / \mathrm{mL}$ chloramphenicol) for genetic manipulation. For protein expression, $1 \mathrm{mM}$ (as a final concentration) of isopropyl- $\beta$-D-thiogalactopyranoside (IPTG; BioBasic, Canada) was added to each culture medium. For in vivo $\mathrm{H}_{2}$ production, cells were grown in $\mathrm{M} 9$ minimal medium (6 g/L Na $\mathrm{Na}_{2} \mathrm{HPO}_{4}, 3 \mathrm{~g} / \mathrm{L} \quad \mathrm{KH}_{2} \mathrm{PO}_{4}, 1 \mathrm{~g} / \mathrm{L}$
$\mathrm{NH}_{4} \mathrm{Cl}, 0.5 \mathrm{~g} / \mathrm{L} \mathrm{NaCl}$, and $1 \mathrm{mg} / \mathrm{L}$ thiamine supplemented with $240.73 \mathrm{mg} / \mathrm{L} \mathrm{MgSO}_{4}, 11.09 \mathrm{mg} / \mathrm{L} \mathrm{CaCl}_{2}$ ) including $5 \mathrm{~g} / \mathrm{L}$ casamino acids and $5 \mathrm{~g} / \mathrm{L}$ glucose. 0.1 $\mathrm{M}$ of $\mathrm{FeSO}_{4}$ and $1 \mathrm{M}$ of $\mathrm{NiSO}_{4}$ solutions were added to $\mathrm{M} 9$ medium at a concentration of $30 \mu \mathrm{M}$ for the functional expression of $H$. marinus [NiFe]-hydrogenase. All cultures were maintained under normal aerobic or micro-aerobic conditions [14]. Cells were grown in serum bottles (125 or $500 \mathrm{~mL}$; Wheaton, USA) sealed with rubber stoppers and aluminum capping at $37^{\circ} \mathrm{C}$ in an air-shaking incubator (Jeiotech, Korea) at a gyration rate of 200-230 rpm. For the assessment of the functional activity of proteorhodopsin, cells were irradiated by $20 \mathrm{~W}$ or $30 \mathrm{~W}$ fluorescent lamps. The light intensity (400-700 nm) at a given location in the culture was measured using a light meter (Apogee, USA) in units of $\mu \mathrm{mol}$ photon $/\left(\mathrm{m}^{2} \cdot \mathrm{s}\right)$.

\section{Plasmid construction}

For the expression of proteorhodopsin in E. coli BL21 (DE3), four genes (Erwinia uredovora crt E, B, I, Y; Genbank: D90087) for $\beta$-carotene synthesis and $\beta$-diox gene for the conversion of $\beta$-carotene to retinal (mouse $\beta$ carotene-15,15'-dioxygenase; Genbank: AF271298) were obtained from pORANGE and $\beta$-plasmid (a kind gift from Dr. J. von Lintig), respectively [20]. $p R$ gene coding for proteorhodopsin (Genbank: AF279106) was also obtained from BAC clone EBAC31A08 (a kind gift from Dr. E. Delong) [7]. All six genes above were amplified by polymerase chain reaction (PCR) using the primers in Table 1 and cloned into the pACYCDuet-1 (Novagen) vector to construct pACYC-RDS (Figure 1), which is compatible with the pET vector. For the expression of $H$. marinus [NiFe]-hydrogenase genes, the pET-HmH vector was used [15]. To analyze the effect of functional proteorhodopsin with retinal, the proteorhodopsin gene $(p R)$, without the genes for retinal synthesis, was cloned into the $\mathrm{pET}-\mathrm{HmH}$ vector to construct $\mathrm{pET}-\mathrm{HmH} / \mathrm{pR}$ (Figure 1).

\section{Measurement of In vivo $\mathrm{H}_{2}$ production}

$\mathrm{H}_{2}$ gas produced in cell culture was obtained from the headspace of a sealed serum bottle (125 or $500 \mathrm{~mL}$ ). Usually, 20-100 $\mu \mathrm{L}$ of the gas sample was analyzed using a gas chromatograph (GC; Younglin Instrument, Korea) equipped with a carboxen-1010 PLOT column (0.53 $\mathrm{mm} \times 30 \mathrm{~m}$, Supelco, USA) and pulsed discharge detector (Valco Instrument, USA). Elution was performed using helium as a carrier gas at a flow rate of $10 \mathrm{~mL} /$ $\mathrm{min}$, and the temperatures of the injector, detector, and oven were set to 130,250 , and $100^{\circ} \mathrm{C}$, respectively. The $\mathrm{H}_{2}$ concentration in the gas sample was calculated using a standard curve. The $\mathrm{H}_{2}$ amount was determined based 
Table 1 Primer sequences for amplification of genes related to $\beta$-carotene synthesis, retinal synthesis, and proteorhodopsin

\begin{tabular}{|c|c|}
\hline Primer name & 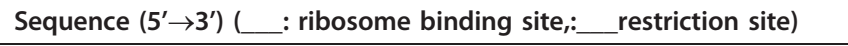 \\
\hline crtE forward & GCCCATGGATGACGGTCTGCGCAAAAAAACACG \\
\hline crtE reverse & GCGAATTCTTAACTGACGGCAGCGAGTTITTG \\
\hline crtB forward & CCGAATTCAAGGAGATATACCAATGAATAATCCGTCGTTACT CAATCATGC \\
\hline crtB reverse & CGGTCGACCTAGAGCGGGCGCTGCCAGAG \\
\hline crtl forward & CCGTCGACAAGGAGATATACAAATGAAACCAACTACGGTAAT TG \\
\hline crtl reverse & CGAAGCTITCATATCAGATCCTCCAGCATC \\
\hline crtY forward & CCAAGCTTGAAGGAGATATACCAATGCAACCGCACTATGATC TGATTCTC \\
\hline crtY reverse & GCCTTAAGTTAGCGATGAGTCGTCATAATGGC \\
\hline$\beta$-diox forward & GGAGATCTAAGGAGATATACATATGGAGATAATATTTGGCCA GAATAAG \\
\hline$\beta$-diox reverse & CCGGTACCTTAAAGACTTGAGCCACCATGACCC \\
\hline pR forward & $\begin{array}{l}\text { CCGGTACCAAGGAGATATACAAATGGGTAAATTATTACTGAT ATTAGGTAG } \\
\text { CCĒGGGCCGCAAGGAGATATACAAATGGGTAAATTATTACTGAT ATTAGGTAG }\end{array}$ \\
\hline$p R$ reverse & GCCTCGAGTTAAGCATTAGAAGATTCTTTAACAGCAAC \\
\hline
\end{tabular}

on the $\mathrm{H}_{2}$ concentration and gas volume of headspace (including expanded volume).

\section{Measurement of absorption spectra of proteorhodopsin}

The absorption spectrum of cells expressing proteorhodopsin was measured using spectrophotometry [7]. To prepare crude membrane fractions, recombinant $E$. coli were harvested by centrifugation at $4^{\circ} \mathrm{C}$ and $4,000 \mathrm{rpm}$ for $15 \mathrm{~min}$. The cell pellet was resuspended in $50 \mathrm{mM}$ Tris- $\mathrm{Cl}$ (pH 6.8) and disrupted with a sonic dismembrator (Fisher Scientific, USA) for $10 \mathrm{~min}$ at $50 \%$ power (5 sec pulse on and 2 sec pulse off). The disrupted cell suspension (total cell lysate) was centrifuged at $4^{\circ} \mathrm{C}$ and $10,000 \mathrm{~g}$ for $20 \mathrm{~min}$. The resultant supernatant (crude extract) was centrifuged at $4^{\circ} \mathrm{C}$ and $120,000 \mathrm{~g}$ for $120 \mathrm{~min}$. The pellet was resuspended in $50 \mathrm{mM}$ Tris- $\mathrm{Cl}(\mathrm{pH} 8.0)$ and $5 \mathrm{mM} \mathrm{MgCl}_{2}$, which is regarded as the crude membrane. The absorption spectrum was measured at spectrum mode using a spectrophotometer (Shimadzu, Japan) after the addition of 20 $\mu \mathrm{M}$ of all-trans-retinal (Sigma).

\section{Conversion efficiency of light energy to $\mathrm{H}_{2}$}

The conversion efficiency of light energy to $\mathrm{H}_{2}$ was calculated using the following equation: conversion efficiency $(\%)=\left(\mathrm{H}_{2}\right.$ production amount $\times \mathrm{H}_{2}$ energy content)/absorbed light energy $\times 100$, where $\mathrm{H}_{2}$ energy content $=10.8 \mathrm{~kJ} / \mathrm{L}$ (lower heating value of $\mathrm{H}_{2}$ ) [19]. Absorbed light energy was calculated using the equation absorbed light energy $(\mathrm{kJ} / \mathrm{s})=0.2176 \mathrm{I}_{\mathrm{o}} \mathrm{S}_{\mathrm{A}}$, where $\mathrm{I}_{\mathrm{o}}=$ incident light intensity $\left(\mu \mathrm{mol} /\left(\mathrm{m}^{2} \cdot \mathrm{s}\right)\right.$ measured by light meter, and $S_{A}=$ illuminated surface area $\left(\mathrm{m}^{2}\right)=\pi \times d \times$ $\mathrm{h}(\mathrm{d}=0.075 \mathrm{~m}, \mathrm{~h}=0.1 \mathrm{~m}$ for the culture in a $500 \mathrm{~mL}$ serum bottle) [21].

\section{Acknowledgements}

This work was supported by the Manpower Development Program for Marine Energy funded by the Ministry of Land, Transport and Maritime Affairs, Korea and the National Research Foundation Grant (NRF-20090093214) and the Brain Korea 21 Program funded by the Ministry of Education, Science and Technology, Korea. We thank Dr. Johannes von Lintig (Case Western Reserve Univ.) and Dr. Edward DeLong (MIT) for their gifts of plasmids.

\section{Author details}

${ }^{1}$ Department of Chemical Engineering, Pohang University of Science and Technology, Pohang 790-784, Korea. ${ }^{2}$ School of Interdisciplinary Bioscience and Bioengineering, Pohang University of Science and Technology, Pohang 790-784, Korea.

\section{Authors' contributions}

JYHK and HJC designed research. JYHK, BHJ, and YJ performed and analyzed biohydrogen production in recombinant $E$. coli. JYHK and HJC wrote the paper. All authors have read and approved the final version of the manuscript.

\section{Competing interests}

The authors declare that they have no competing interests.

Received: 22 December 2011 Accepted: 4 January 2012 Published: 4 January 2012

\section{References}

1. Walter JM, Greenfield D, Liphardt J: Potential of light-harvesting proton pumps for bioenergy applications. Curr Opin Biotechnol 2010, 21:265-270.

2. Bhattacharya S, Schiavone M, Nayak A, Bhattacharya SK: Biotechnological storage and utilization of entrapped solar energy. App/ Biochem Biotechnol 2005, 120:159-167.

3. Atsumi S, Liao JC: Direct photosynthetic recycling of carbon dioxide to isobutyraldehyde. Nat Biotechnol 2009, 27:1177-1180.

4. Hu Q, Sommerfeld M, Jarvis E, Ghirardi M, Posewitz M, Seibert M, Darzins A: Microalgal triacylglycerols as feedstocks for biofuel production: perspectives and advances. The Plant J 2008, 54:621-639.

5. Eroglu E, Melis A: Photobiological hydrogen production: recent advances and state of the art. Bioresour Technol 2011, 102:8403-8413.

6. Beer $L L$, Boyd ES, Peters JW, Posewitz MC: Engineering algae for biohydrogen and biofuel production. Curr Opin Biotechnol 2009, 20:264-71. 
7. Béjà $\mathrm{O}$, Aravind $\mathrm{L}$, Koonin $\mathrm{EV}$, Suzuki $M T$, Hadd $A$, Nguyen $L P$, Jovanovich SB, Gates CM, Feldman RA, Spudich JL, Spudich EN, DeLong EF: Bacterial rhodopsin: evidence for a new type of phototrophy in the sea. Science 2000, 289:1902-1906.

8. DeLong EF, Béjà O: The light-driven proton pump proteorhodopsin enhances bacterial survival during tough times. PLOS Biol 2010, 8: e1000359.

9. Gomez-Consarnau L, Gonzalez JM, Coll-Llado M, Gourdon P, Pascher T, Neutze R, Pedros-Alio C, Pinhassi J: Light stimulates growth of proteorhodopsin-containing marine Flavobacteria. Nature 2007, 445:210-213.

10. Walter JM, Greenfield D, Bustamante C, Liphardt J: Lightpowering Escherichia coli with proteorhodopsin. Proc Natl Acad Sci USA 2007, 104:2408-2412.

11. Johnson ET, Baron DB, Naranjo B, Bond DR, Schmidt-Dannert C, Gralnick JA: Enhancement of survival and electricity production in an engineered bacterium by light-driven proton pumping. Appl Environ Microbiol 2010, 76:4123-4129.

12. Park JH, Lee $D$, Lee HC, Park ED: Steam reforming of liquid petroleum gas

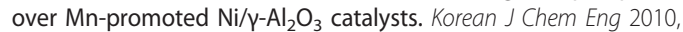
27:1132-1138.

13. Kim JYH, Jung HJ, Cha HJ: Universal degenerate oligonucleotide-primed polymerase chain reaction for detection and amplification of NiFehydrogenase genes. Enzyme Microb Technol 2007, 42:1-5.

14. Kim JYH, Jo BH, Cha HJ: Production of biohydrogen by recombinant expression of [NiFe]-hydrogenase 1 in Escherichia coli. Microbial Cell Fact 2010, 9:54.

15. Kim JYH, Jo BH, Cha HJ: Production of biohydrogen by heterologous expression of oxygen-tolerant Hydrogenovibrio marinus [NiFe]hydrogenase in Escherichia coli. J Biotechnol 2011, 155:312-319.

16. McKinlay JB, Harwood CS: Photobiological production of hydrogen gas as a biofuel. Curr Opin Biotechnol 2010, 21:244-251.

17. Dasgupta CN, Gilbert J, Lindblad P, Heidorn T, Borgvang SA, Skjanes K, Das D: Recent trends on the development of photobiological processes and photobioreactors for the improvement of hydrogen production. Int J of Hydrogen Energ 2011, 35:10218-10238.

18. Heberle J, Riesle J, Thiedemann G, Oesterhelt D, Dencher NA: Proton migration along the membrane surface and retarded surface to bulk transfer. Nature 1994, 370:379-384.

19. Akkerman I, Janssenb M, Rochac J, Wijlels RH: Photobiological hydrogen production: photochemical efficiency and bioreactor design. Int $J$ Hydrogen Energ 2002, 27:1195-1208.

20. Von Lintig J, Vogt K: Filling the gap in vitamin A research. Molecular identification of an enzyme cleaving $\beta$-carotene to retinal. J Biol Chem 2000, 275:11915-11920

21. Ogbonna JC, Yada H, Masui H, Tanaka H: A Novel internally illuminated stirred tank photobioreactor for large-scale cultivation of photosynthetic cells. J Ferment Bioeng 1996, 82:61-67.

doi:10.1186/1475-2859-11-2

Cite this article as: Kim et al:: Improved production of biohydrogen in light-powered Escherichia coli by co-expression of proteorhodopsin and heterologous hydrogenase. Microbial Cell Factories 2012 11:2.

\section{Submit your next manuscript to BioMed Central and take full advantage of:}

- Convenient online submission

- Thorough peer review

- No space constraints or color figure charges

- Immediate publication on acceptance

- Inclusion in PubMed, CAS, Scopus and Google Scholar

- Research which is freely available for redistribution

Submit your manuscript at www.biomedcentral.com/submit
Biomed Central 